DOI: $10.19195 / 0137-1134.119 .14$

\author{
ARTUR ŁAWNICZAK \\ ORCID: 0000-0002-0611-7176 \\ Uniwersytet Wrocławski
}

\title{
NAJWYŻSZA RADA SĄDOWNICTWA W RUMUNII
}

\begin{abstract}
Abstrakt: Podobnie jak w wielu innych państwach, również w Rumunii umieszczono w prawnopolitycznym krajobrazie Krajową Radę Sądownictwa. Jest to podmiot niewystępujący w klasycznym konstytucyjnym schemacie ustroju politycznego. Został on umieszczony w przestrzeni między najwyższymi władzami państwowymi a sądami. Jego skład personalny jest konstytuowany przez przedstawicieli środowiska sędziowskiego i prokuratury oraz członków wybranych przez Senat. Racją bytu Rady jest przedstawianie prezydentowi kandydatów na stanowiska w sędziowsko-prokurakotorskim segmencie władzy państwowej.
\end{abstract}

Słowa kluczowe: rada, Rumunia, sądownictwo, konstytucja

Intensywnie dbająca o to, aby spełniać jak najwięcej eurostandardów, Rumunia ma generalnie podobny system prawnoustrojowy jak ,typowe dojrzałe i dojrzewające demokracje". Nie dziwi zatem specjalnie to, że obowiązuje w niej podział władzy ${ }^{1}$, z czego wynika, że judykatura cieszy się, przynajmniej teoretycznie, sporą dozą samodzielności ${ }^{2}$. W jej utrzymaniu oraz właściwej realizacji typowych dla trzeciej władzy zadań ma walnie pomagać organ noszący nazwę Najwyższej Rady Sądownictwa (Consiliul Superior al Magistraturii).

Instytucja ta ma się przyczyniać do tego, żeby art. 1 ust. 3 Konstytucji Rumunii, głoszący, że jest ona państwem prawa, nie pozostał martwą literą. Co prawda główną rolę w dziele kultywowania czy też wzmacniania nomokratyczności powi-

1 Rumuński autor dostrzega w niej najważniejszą formalną gwarancję funkcjonowania państwa prawa, dzięki której nie dochodzi do gromadzenia różnych władz w jednym podmiocie i mogą one wzajemnie się kontrolować — D.C. Dănişor, Principii generale, [w:] idem, Constituţia României comentată, Bucureşti 2009, s. 41.

2 Warto tu przytoczyć opinię „czołowego teoretyka rumuńskiego ruchu socjalistycznego”, jakim był Dobrogeanu-Gherca. Stwierdził on w swoim czasie, że „u nas stosunki prawne są znacznie bardziej rozwinięte niż pozostała rzeczywistość" - G.N. Niegru, Ocenka social'no-politiczeskich i ekonomiczeskich wzgladow K. Dobrodżanu-Gieri w sowietskoj istoriografi, [w:] Problemy istorii Rumynii, red. S.A. Madijewskij et al., Kisziniew 1988, s. 90; C. Dobrogeanu-Gherca, Opere complete, t. 3, Bucureşti 1977, s. 185. 
nien odgrywać Trybunał Konstytucyjny (Curtea Constituţională), ale nie oznacza to przecież, że inne organy nie mają nic do powiedzenia w tej sferze. W oczywisty sposób są nimi sądy, oceniające, czy nie doszło do naruszenia przepisów przez ludzi. Oprócz władzy sądowniczej w jej klasycznej oraz konstytucyjnej postaci na niwie przestrzegania praworządności pojawiły się w dziejowym rozwoju także inne podmioty mające pomagać w funkcjonowaniu wymiaru sprawiedliwości. Do tej właśnie kategorii wypada zaliczyć rady sądownicze. Nie zajmują się one bieżącym orzekaniem, dzięki czemu ich członkowie mogą z pewnego dystansu obserwować działania sądów, co powinno sprzyjać podejmowaniu właściwych decyzji, optymalnych zarówno dla sądownictwa, jak i całej państwowości.

Prapoczątków tego rodzaju instytucji na rumuńskich ziemiach wypada poszukiwać w otaczających hospodarskie trony Mołdawii oraz Wołoszczyzny bojarach, którzy służyli władcom poradą oraz byli przez nich wykorzystywani jako pierwszorzędni realizatorzy monarchicznej woli. Konstytuowali oni naddunajskie odpowiedniki rozpowszechnionej w Europie instytucji curia regis, będącej zapowiedzią zarówno wyższej izby parlamentu, jak i najwyższego sądu. W wypadku prerumuńskich hospodarstw możemy mówić o otaczających panujących radach bojarskich ${ }^{3}$. Podobnie jak w innych państwach hospodar nie mógł osobiście zajmować się wszystkim, w związku z czym przekazywał obsługiwanie niektórych obszarów władania zaufanym osobom, zastrzegając sobie prawo do podjęcia ostatecznej decyzji w szczególnie istotnych czy też kontrowersyjnych sprawach.

W nowszych czasach w sporej mierze na odcinku koordynowania działalności właściwych organów wymiaru sprawiedliwości w postaci sądów zadania spełniane onegdaj przez bojarów przejęło Ministerstwo Sprawiedliwości, kopiujące popularne w zachodnich krajach administracyjne rozwiązanie, ale pojawienie się takiej, rzucającej wyzwanie dosłownie rozumianemu dogmatowi podziału władzy, instytucji nie oznacza bynajmniej, że zamknięto drogę innym „okołosądowym” bytom. Do takiej właśnie kategorii wypada zaliczyć Najwyższą Radę Sądownictwa, skoro została ona umieszczona w Konstytucji Rumunii w jej rozdziale VI, noszącym nazwę „Władza sądownicza”.

Wynika z tego, że trzecia władza jak najbardziej podlega internalnej dywersyfikacji. W wypadku omawianej w tym tekście części sensu largo sądownictwa konieczność istnienia takiego organu jak Rada wynika z przekonania o niezbędności podmiotu znajdującego się między najwyższą władzą w państwie a sądami jako takimi, które tworzą wszak fragment większej całości, z czego wynika, że nie mogą być zupełnie pozostawione same sobie, gdyż groziłoby to daleko posuniętą anarchizacją życia publicznego.

Aby temu przeciwdziałać, powołano do życia organ, który ma pełnić funkcję pośrednika, względnie pasa transmisyjnego między sądami a pozostałą częścią

3 Były one prefiguracją istniejącej w socjalistycznej Rumunii Rady Państwa (Consiliul de Stat al României), będącej w latach 1961-1989 trwałym elementem prawno-politycznego pejzażu. 
zinstytucjonalizowanej władzy państwowej. Najwyższa Rada Sądownictwa zgodnie z art. 133 ust. 1 Konstytucji Rumunii ma być organem, który gwarantuje niezależność sądownictwa ${ }^{4}$. Rada składa się z 19 członków, przy czym istnieją trzy różne metody obsadzania jej składu personalnego.

Pierwszy sposób doboru, odnoszący się do dziewięciu z całej dziewiętnastki zindywidualizowanych „gwarantów sędziowskiej niezawisłości” ma sędziowsko-parlamentarny charakter, ponieważ w tych przypadkach wyboru dokonują sędziowskie zgromadzenia, których rozstrzygnięcia są następnie zatwierdzane przez Senat. Mamy tu zatem do czynienia z sensu largo kooptacją, ponieważ nie dość, że zdecydowana większość piastunów szczególnego rodzaju konstytucyjnej władzy pochodzi ze środowiska sędziowskiego, to na dodatek ono samo wyznacza kandydatów. Takie rozwiązanie ma merytoryczne uzasadnienie, gdyż istnieje wszak domniemanie co do dogłębnej orientacji ludzi ferujących w majestacie prawa wyroki w najbardziej zawikłanych aspektach wymiaru sprawiedliwości.

Dlatego też, aby zrównoważyć ten paradygmat, postanowiono, że decyzje sędziowskich zgromadzeń muszą być zatwierdzane przez Senat (art. 133 ust. 2 p. a. Konstytucji). To odwołanie się do wyższej izby parlamentu nie jest przypadkowe, bo to właśnie on jest następcą mołdawsko-wołoskich bojarskich rad, konstytuowanych przez osoby zbliżone swoją, przynajmniej teoretyczną, godnością do senatorów. W wielu krajach to właśnie konstytuowanej przez nich ,izbie rozsądku i refleksji" przyznaje się mające sądowniczy charakter uprawnienia. Jest ona w mniejszym stopniu niż druga część legislatywy wciągnięta w bieżącą rywalizację polityczną, co stwarza nadzieję, że jej rozstrzygnięcia będą miały merytoryczny, abstrahujący od „rozgorączkowanej politycznej bieżączki” posmak. Poza wszystkim, skoro już decydujemy się na bikameralizm, to trzeba jakieś kompetencje przyznać każdej z izb.

Oparty na tej samej filozofii schemat doboru członków znajduje zastosowanie w odniesieniu do kolejnych pięciu współczłonków Rady. Są oni najpierw rekomendowani przez prokuratorskie zgromadzenia, po czym Senat aprobuje te propozycje lub nie (art. 133 ust. 2 p. a.).

Widzimy, że ustrojodawca uznał, że oprócz sędziowskiej frakcji w omawianym tutaj organie powinno się też znaleźć miejsce dla przedstawicieli prokuratury. Jak zwykle można się zastanawiać nad słusznością takiego rozstrzygnięcia. Niewątpliwie prokuratura odgrywa istotną rolę w wymiarze sprawiedliwości, będąc w klasycznym procesie jedną ze stron sądowego pojedynku, niemniej jednak nie należy żywić przesadnych oczekiwań co do tego, że reprezentanci tej części aparatu władzy państwowej będą mówić własnym głosem, gdyż, w przeciwieństwie do sędziów, w doktrynalno-instytucjonalnym wymiarze nie są oni niezależni. Wszakże, spoglądając z perspektywy ogólnopaństwowego interesu, umieszcze-

4 Constituţia României, publicat in Monitorul Oficial nr 767 din 31 octombrie 2003, http:// www.ucv.ro/pdf/site/constitutia_romaniei.pdf (dostęp: 16.09.2018). 
nie prokuratorów w łonie Rady ma swój sens, ponieważ osłabiają oni sędziowską dominację $\mathrm{w}$ tym gremium.

Kolejni dwaj członkowie Rady nie przynależą już do upaństwowionego, sprofesjonalizowanego sędziowsko-prokuratorskiego establishmentu wymiaru sprawiedliwości. Ustrojodawca życzy sobie w kolejnym fragmencie art. 133, aby obaj byli reprezentantami społeczeństwa obywatelskiego (societaţie civilă). Inaczej rzecz ujmując, ich obecność w organie, mającym zabezpieczać czy też uwiarygadniać funkcjonowanie sądownictwa oraz związanych z nim jurydycznych struktur, ma demonstrować urbi et orbi, że aparat państwowy nie jest wyalienowany, gdyż utrzymuje permanentne więzy z niezinstytucjonalizowanym narodem, z czego wynikałoby, że doktrynalny suweren uzyskuje specjalne uprawnienie wglądu, rzecz jasna przez swoich pełnomocników, w prace Rady.

Wszakże bynajmniej nie jest tak, że owi eksponenci społeczeństwa mogą pochodzić z dowolnej jego warstwy, ponieważ mają być oni ,specjalistami w dziedzinie prawa”, cieszącymi się na dodatek ,ugruntowaną zawodową i moralną reputacją". Ten drugi zwrot ma w zasadzie retoryczno-propagandowy charakter, bo przecież ludowładztwo raczej dystansuje się od aksjologicznych uwarunkowań. W dzisiejszym świecie reputacja jest w przemożnej mierze kreowana przez media, narzucające ich odbiorcom własną narrację. W takim stanie rzeczy ,ugruntowana reputacja" w jakiejkolwiek dziedzinie staje się coraz trudniejsza do osiągnięcia.

Gdy wgłębimy się w interpretację określenia „specjaliści w dziedzinie prawa”, to bez ryzyka większej pomyłki można zgadywać, że chodzi o zajmujących się prawem i wysoko usytuowanych w sztywno sformalizowanej, opartej na zdobywanych z mniejszym lub większym mozołem tytułach i stopniach, scjentystycznej hierarchii, pracownikach jurydycznych fakultetów lub znaczących przedstawicieli adwokatury, notariatu czy też radców prawnych. Ludzie tego pokroju tworzą naturalne zaplecze sądownictwa, które nie działa przecież w społecznej próżni, co oznacza, że potrzebna jest merytorycznie nacechowana otoczka, będąca swego rodzaju pasem transmisyjnym między „,sędziowskim światkiem” a nieorientującą się za bardzo w prawnonormatywnych zawiłościach resztą rumuńskiego narodu politycznego.

Jeśli chodzi o to, kto dokona wyboru dwóch członków Rady spoza sędziowsko-prokuratorskiego paradygmatu, to ową kompetencję przyznano Senatowi, uznanemu za odpowiednie do tego gremium $\mathrm{z}$ wyłuszczonych już względów. W przeciwieństwie do schematu rekrutacji 14 członków z łona wymiaru sprawiedliwości w wypadku dwóch następnych decyzja podejmowana jest samodzielnie przez wyższą izbę legislatywy (art. 133 ust. 2 p. b.), obdarzoną domniemaniem zbiorowej mądrości ${ }^{5}$.

${ }^{5}$ Wszak nie należy zapominać o starołacińskiej sentencji senatores boni viri, senatus mala bestia. Ludzie, również politycy, gdy działają pojedynczo, niejednokrotnie zachowują się rozsądnie, natomiast w tłumie czy też w „tłumku” często bywa inaczej. Zob. G. Le Bon, Psychologia tłumu, Komorowo 2004, passim. 
Ustrojodawca uznał, że dwaj przedstawiciele społeczeństwa obywatelskiego nie powinni w takim samym zakresie jak pozostała czternastka partycypować w poczynaniach Rady. Przekonanie to wyraziło się w tym, że wybrani przez Senat spoza upaństwowionego wymiaru sprawiedliwości znawcy jurydycznych arkanów mogą brać udział wyłącznie w jej plenarnych pracach.

Trzecią część członków Rady współkonstytuują ludzie, którzy wchodzą w jej skład z racji piastowania poważnych stanowisk w strukturach upaństwowionej władzy. Są nimi Minister Sprawiedliwości, Prezes Najwyższego Sądu Kasacji i Sprawiedliwości oraz Prokurator Generalny przy Najwyższym Sądzie Kasacji i Sprawiedliwości (art. 133 ust. 2 p. c.). Uzupełnienie personalnego składu Rady przez tego rodzaju republikańskich funkcjonariuszy niekoniecznie utwierdza w przekonaniu, że zadekretowana przez ustrojodawcę tożsamość tego organu odpowiada prawnopolitycznej rzeczywistości. Wszak samo istnienie takich instytucji jak wnikliwie obserwujący poczynania sądownictwa Minister Sprawiedliwości czy też koordynujący poczynania swoich podwładnych Główny Prokurator rzuca wyzwanie dogmatowi sędziowskiej niezawisłości, ewidentnie ograniczanej przez wszelakie poczynania wymienionych wcześniej podmiotów. Trudno przecież negować, że racją ich bytu jest oddziaływanie na poczynania szafarzy sprawiedliwości, realizujących swą misję bynajmniej nie w próżni, lecz w określonym prawnopaństwowym systemie, którego logika wymusza na nich dostosowanie się do jego tożsamości, co sprawia, że nikt rozsądny nie zaneguje nieuchronności upolitycznienia wszelkiej maści sądownictwa, będącego ex definitione jedną z postaci sprawowania władztwa.

W dalszych swoich częściach art. 133 Konstytucji rozstrzyga o innych ważnych zagadnieniach związanych z NRS-em. Dowiadujemy się zatem, że jej kadencja wynosi sześć lat (art. 133 ust. 4), z czego wynika, że nie zasiada się w niej dożywotnio, co byłoby najlepszą rękojmią niezależności poczynań członków tego szacownego gremium. Jednakże takie rozwiązanie byłoby niezgodne z republikańskim dogmatem kadencyjności, choć jak dość powszechnie wiadomo, w „pokazowo republikańskich w nowożytnych czasach Stanach Zjednoczonych Ameryki” w odniesieniu do sądownictwa $\mathrm{z}$ łatwością odchodzi się od tego nakazu. $\mathrm{Z}$ kolei według starożytnego, rzymskiego wzorca kadencja powinna być krótka, sześciomiesięczna lub roczna. Mamy tu więc do czynienia z kompromisem, skutkującym dość długim okresem sprawowania funkcji, co nie oznacza, że nie odnajdziemy we współczesnym świecie (wystarczy zajrzeć do rodzimej ustawy zasadniczej) bardziej rozciągniętych kadencji.

A contrario w odniesieniu do obsadzania stanowiska przewodniczącego Rady sięgnięto do antycznych przekonań, skoro uznano, że nikt nie powinien dłużej niż rok zajmować tak dystyngowanego stanowiska i nie przewiduje się możliwości ponownego objęcia tego prestiżowego urzędu przez tę samą osobę. Ustrojodawca w swojej przenikliwości uznał, że tak wysoko mogą wspiąć się tylko pierwszorzędni członkowie Rady, co oznacza, że zaszczyt ten może spaść jedynie na sędziego lub prokuratora (art. 133 ust. 3). 
Ten, któremu uda się tak wysoko wspiąć, musi wszakże liczyć się z tym, że zostanie krótkookresowo odsunięty od kierowania pracami podległej mu instytucji. Dzieje się tak wówczas, gdy na obrady przybywa sam prezydent Republiki (art. 133 ust. 6), bo nie wypada przecież, żeby Pierwszy Obywatel komuś podlegał. Jeśli chodzi o sposób podejmowania decyzji przez NRS, to ustawa zasadnicza formułuje wymóg nacechowanego tajnością głosowania (art. 133 ust. 5), co skłania do zastanowienia, bo przecież, w odróżnieniu od powszechnych wotowań, w parlamentarnych gremiach raczej oddaje się głosy ,z otwartą przyłbicą”. Jednakże w wypadku Rady twórcy Konstytucji uznali, że byłaby to przesada i lepiej zagwarantować współgłosującym, wynikający z przykrycia woalem tajemniczości ich osobistych wyborów, komfort.

Dokonane w ten sposób rozstrzygnięcia cieszą się statutem ostateczności i nieodwołalności. Ale jak to często bywa, nie jest to żelazna reguła, nie obowiązuje bowiem w odniesieniu do kończących wszczynane przeciw sędziom lub prokuratorom dyscyplinarnych postępowań postanowień (art. 133 ust. 7).

Gdy przejdziemy z opisu strukturalnych różnorodności NRS-u do zaprezentowania jego prawno-politycznego rozmachu, okaże się, że ma on dość ograniczony zakres. Okazuje się, że organ ten pojawił się w rumuńskim prawno-politycznym paradygmacie przede wszystkim po to, by przedkładać prezydentowi Rumunii spersonalizowane propozycje, skłaniające głowę państwa do ulokowania właśnie tych, a nie innych kandydatów w gronie dyplomowanych, obdarzonych odgórną ogólnopaństwową aprobatą, sędziów i prokuratorów, przy czym zakres tej kompetencji nie rozciąga się na sędziów-stażystów (art. 134 ust. 1). Takie rozwiązanie można interpretować jako brak zaufania do Prezydenta, który przecież ma własne kanały informacji i mógłby w związku z tym samodzielnie, bez jakichkolwiek zinstytucjonalizowanych podpowiedzi, obdarzać sędziowską oraz prokuratorską godnością tych absolwentów jurydycznych fakultetów, którzy po uporaniu się z wszelkimi dodatkowymi wymogami wyrazili chęć wstąpienia do stricte jurydycznej części aparatu państwowego władania.

Rumuńskie rozwiązanie, któremu trudno przypisać znamię szczególnej oryginalności, sprzyja wyalienowaniu wymiaru sprawiedliwości od pozostałego społeczeństwa. Nie ma ono wszak większego wpływu na jego personalną obsadę. W instytucjonalnym wymiarze dostrzeżemy jego istnienie, dopiero gdy przypomnimy sobie, że Prezydent jest wybierany w powszechnej elekcji, a większość członków NRS-u jest aprobowana przez również mający ogólnonarodową oddolną legitymizację Senat.

Drugim, wspomnianym już, uprawnieniem Rady jest wydawanie orzeczeń we wszczynanych przeciwko sędziom i prokuratorom postępowaniach dyscyplinarnych. Ustrojodawca rozstrzygną, że podczas podejmowania tego rodzaju decyzji Minister Sprawiedliwości, Prezes Wysokiego Trybunału Kasacyjnego i Sprawiedliwości oraz Prokurator Generalny przy tymże Trybunale nie biorą udziału w głosowaniu. Należące do tej kategorii postanowienia mogą być zaskarżane, po 
czym w drugiej instancji ostateczne rozstrzygnięcie przysługuje Wysokiemu Trybunałowi Kasacyjnemu i Sprawiedliwości (art. 134 ust. 2 i 3).

Summa summarum omawiany w tym tekście organ jawi się jako byt, który ma pełnić funkcję łącznika między wymiarem sprawiedliwości a pozostałą częścią aparatu państwowego. Doktrynalnie rzecz ujmując, gdyby dogmatycznie stanąć na twardym gruncie dogmatu podzielności władzy, to istnienie NRS-u nieszczególnie jest z nim zgodne, zwłaszcza gdy uwzględnimy, że w pracach tej instytucji może brać udział reprezentujący egzekutywę prezydent (choć jednocześnie jest on ,unoszącym się ponad lockowsko-monteskiuszowskimi dystynkcjami ogólnopaństwowym zwornikiem"). Rada ma reprezentować interesy sędziowsko-prokuratorskiego środowiska, co w jakimś stopniu zaciera różnice między trzecią władzą a „występującymi podczas procesów w togach innego koloru zawziętymi oskarżycielami”, z czego wynikałoby, że jej istnienie niekoniecznie jest zgodne z lansowanym w konstytucyjno-politycznym wymiarze wizerunkiem sędziowskiej niezawisłości.

\section{THE SUPERIOR COUNCIL OF MAGISTRACY IN ROMANIA}

\section{Summary}

In the constitutional scheme of state power in Romania we can find the Superior Council of Magistracy. This subject is absent in the classical version of the political system. The Council is situated between the highest state powers and the courts. Its personal composition is constituted by delegates of the judiciary and public prosecutor's office, as well as persons elected by the Senat. The task of the Council is presentation of judicial and prosecutor's candidatures for the Presidency.

Keywords: council, Romania, judiciary, constitution

\section{BIBLIOGRAFIA}

Dănişor D.C., Principii generale, [w:] idem, Constituţia României comentată, București 2009.

Dobrogeanu-Gherca C., Opere complete, t. 3, Bucureşti 1977.

Le Bon G., Psychologia ttumu, Komorowo 2004.

Niegru G.N., Ocienka social'no-politiczeskich i ekonomiczeskich wzgliadow K. Dobrodżanu-Gieri w sowietskoj istoriografii, [w:] Probliemy istorii Rumynii, red. S.A. Madijewskij, I.E. Liewit, K.A. Moszanu, K.L. Żignja, W.I. Mokrjak, Kisziniew 1988. 